\title{
Preparation and Crystal Structure of Zinc Bis[orotate(1-)] Octahydrate
}

Otto Kumberger, Jürgen Riede, and Hubert Schmidbaur*

Anorganisch-chemisches Institut der Technischen Universität München, Lichtenbergstraße 4, D-85747 Garching

Z. Naturforsch. 48b, 961-964 (1993); received April 7, 1993

Metal Orotates, Orotic Acid, Hydrogen Bonding, X-Ray

A discrete zinc bis[orotate(1-)] complex of the composition $\mathrm{Zn}(\mathrm{OrH})_{2} \cdot 8 \mathrm{H}_{2} \mathrm{O}$ has been isolated and characterized by a single-crystal X-ray structure analysis. The crystals are monoclinic, space group P $2_{1} / c$ (No. 14), $Z=2, a=10.884(2), b=12.896(1), c=6.954(1) \AA, \beta=$ $98.27(1)^{\circ}$. The crystal lattice features hexaquo complexes of zinc, the $\mathrm{Zn}\left(\mathrm{H}_{2} \mathrm{O}\right)_{6}{ }^{2+}$ cations being associated with two hydrated $\mathrm{OrH}^{-}$ions only through hydrogen bonds. The results are relevant for applications of zinc orotates in medical treatment.

\section{Introduction}

Orotic acid [6-uracilcarboxylic acid, $\mathrm{OrH}_{2}(\mathbf{1})$, vitamin $B_{13}$ and its salts and other derivatives play an important role in the metabolism of pyrimidine nucleotides $[1,2]$ and are found in cells and body fluids of many living organisms. Metal orotates are also widely applied in medicine. Recent interest has focused on the proposed biological carrier function of orotic acid and the corresponding anionic species for metal ions, which is held responsible for the obviously successful application of metal orotates in curing syndroms associated with a deficiency of a variety of metals such as calcium, magnesium, zinc or iron [3].<smiles>O=C(O)c1cc(=O)[nH]c(=O)[nH]1</smiles>

As part of a program oriented towards elucidation of the metal binding properties of orotic acid [3-6], we have recently described the preparation, crystallization, and X-ray structure analysis of a new discrete zinc orotate (2-) phase of the composition $\mathrm{Zn}(\mathrm{Or}) \cdot 5.5 \mathrm{H}_{2} \mathrm{O}$ [5]. Very surprisingly this phase was obtained from an aqueous solution containing the zinc ion and the orotate ligand in molar ratios as high as 1:2 and in an intermediate $\mathrm{pH}$ range $(\mathrm{pH}=5.4)$. Crystallization of

\footnotetext{
* Reprint requests to Prof. Dr. H. Schmidbaur.

Verlag der Zeitschrift für Naturforschung,

D-72072 Tübingen

0932-0776/93/0700-0961/\$01.00/0
}

$\mathrm{Zn}(\mathrm{Or}) \cdot 5.5 \mathrm{H}_{2} \mathrm{O}$ was accomplished by layering this aqueous solution with acetone. The compound features $\mathrm{Zn}(\mathrm{Or})\left(\mathrm{H}_{2} \mathrm{O}\right)_{4}$ units (Fig. 1). No zinc(II) bis[orotates $(1-)] \mathrm{Zn}(\mathrm{OrH})_{2}$ were detected under these conditions, although the acid/base equilibria and the stoichiometry should have favoured their formation.

We now report the preparation, crystallization and X-ray structure determination of zinc bis[orotate(1-)] octahydrate $\mathrm{Zn}(\mathrm{OrH})_{2} \cdot 8 \mathrm{H}_{2} \mathrm{O}$.

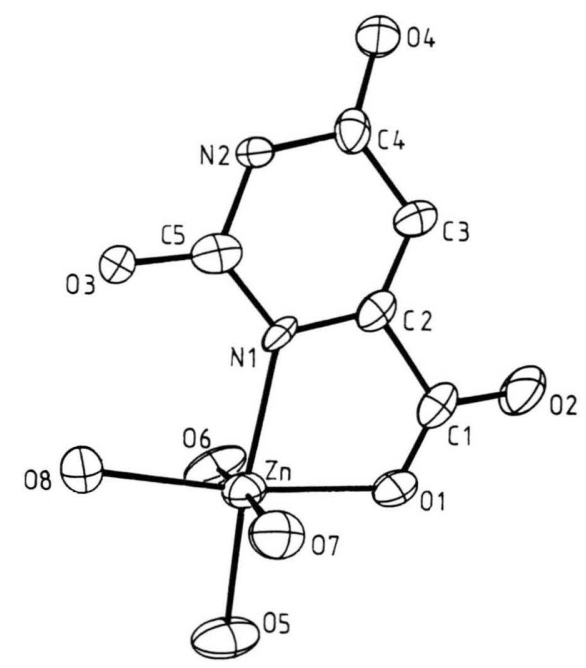

Fig. 1. $\mathrm{Zn}(\mathrm{Or})\left(\mathrm{H}_{2} \mathrm{O}\right)_{4}$ Unit in the Crystal Structure of $\mathrm{Zn}(\mathrm{Or}) \cdot 5.5 \mathrm{H}_{2} \mathrm{O}$.

\section{Experimental}

All reactions were carried out in pure, desalinated water. Reagents were of p.a. quality. A Knick apparatus $(\mathrm{AgCl} / \mathrm{KCl})$ was used for $\mathrm{pH}$ readings. 


\section{Zinc bis[orotate (1-)] Joctahydrate}

A suspension of $0.50 \mathrm{~g}(3.20 \mathrm{mmol})$ of orotic acid in $40 \mathrm{ml}$ of water was treated with $0.13 \mathrm{~g}$ $(1.60 \mathrm{mmol})$ of $\mathrm{ZnO}$ at reflux temperature. The resulting suspension ( $\mathrm{pH}$ 5.4) was filtered, left to cool to room temperature, and the volume reduced to $10 \mathrm{ml}$ in a vacuum. Slow evaporation of the solution yielded after 2 months colourless crystals $\left(0.15 \mathrm{~g}, 0.29 \mathrm{mmol}\right.$; yield: $18 \%$; m.p. $\left.>350{ }^{\circ} \mathrm{C}\right)$. The elemental analysis of the crystals indicated the composition $\mathrm{Zn}(\mathrm{OrH})_{2} \cdot 8 \mathrm{H}_{2} \mathrm{O}$ :

\section{Calcd C 23.11 H 4.27 N 10.78\%, Found C 22.26 H 4.22 N 10.10\%.}

The crystals were suitable for X-ray structure analysis.

\section{Crystallographic data}

$\mathrm{Zn}(\mathrm{OrH})_{2} \cdot 8 \mathrm{H}_{2} \mathrm{O} ; \quad \mathrm{C}_{10} \mathrm{H}_{22} \mathrm{~N}_{4} \mathrm{O}_{16} \mathrm{Zn}, \quad \mathrm{M}_{\text {rel }}=$ 519.674, monoclinic, space group $\mathrm{P} 2_{1} / c$ (Nr. 14), $a=10.884(2), b=12.896(1), c=6.954(1) \AA, \beta=$ $98.27(1)^{\circ}, \mathrm{V}=965.91 \AA^{3}, Z=2, \mathrm{D}_{\text {calc }}=$ $1.787 \mathrm{~g} \mathrm{~cm}^{-3}, \mathrm{~F}(000)=536, \mu(\mathrm{MoK} \alpha)=13.9$.

Data collection: CAD 4 diffractometer $(\mathrm{MoK} \alpha$ radiation, $\lambda=0.71069 \AA$, graphite monochromator, $\omega$-scan, $\mathrm{T}=23^{\circ} \mathrm{C}$ ). Lp correction, 1686 independent structure factors, 1536 observed $\left[\mathrm{F}_{\mathrm{o}} \geq\right.$ $\left.1 \sigma\left(\mathrm{F}_{\mathrm{o}}\right)\right] ; 11$ hydrogen atoms located and refined with isotropic displacement factors. $R\left(R_{\mathrm{w}}\right)=$ $0.026(0.024)$ for 186 refined parameters, residual electron density $+0.36 /-0.36 \mathrm{e}^{-3}$. Final atomic coordinates and equivalent displacement factors are presented in Table I. Further details of the crystal structure determination are available on re-

Table I. Fractional atomic coordinates and thermal displacement parameters for $\mathrm{Zn}(\mathrm{OrH})_{2} \cdot 8 \mathrm{H}_{2} \mathrm{O}$.

\begin{tabular}{llrll}
\hline Atom & $x / a$ & \multicolumn{1}{l}{$y / b$} & \multicolumn{1}{l}{$z / c$} & $\mathrm{U}_{\text {eq }}$ \\
\hline Zn & 0.00000 & 0.00000 & 0.00000 & 0.024 \\
O1 & $0.3339(1)$ & $-0.3566(1)$ & $0.5609(2)$ & 0.028 \\
O2 & $0.1920(1)$ & $-0.2467(1)$ & $0.4151(2)$ & 0.029 \\
O3 & $0.3902(1)$ & $0.0953(1)$ & $0.6670(2)$ & 0.030 \\
O4 & $0.6703(2)$ & $-0.1564(1)$ & $0.8725(3)$ & 0.040 \\
O5 & $0.1769(1)$ & $0.0098(2)$ & $-0.0591(2)$ & 0.029 \\
O6 & $0.0231(2)$ & $0.1433(1)$ & $0.1509(3)$ & 0.029 \\
O7 & $0.0494(2)$ & $-0.0796(1)$ & $0.2662(3)$ & 0.035 \\
O8 & $-0.1387(2)$ & $-0.1621(2)$ & $0.4638(3)$ & 0.037 \\
N 1 & $0.4861(2)$ & $-0.2041(1)$ & $0.6999(3)$ & 0.022 \\
N2 & $0.5269(2)$ & $-0.0319(1)$ & $0.7689(3)$ & 0.024 \\
C1 & $0.2918(2)$ & $-0.2681(2)$ & $0.5181(3)$ & 0.020 \\
C2 & $0.3726(2)$ & $-0.1782(2)$ & $0.6016(3)$ & 0.019 \\
C3 & $0.3349(2)$ & $-0.0788(2)$ & $0.5855(3)$ & 0.022 \\
C4 & $0.4145(2)$ & $0.0020(2)$ & $0.6732(3)$ & 0.022 \\
C5 & $0.5689(2)$ & $-0.1327(2)$ & $0.7869(3)$ & 0.025 \\
\hline
\end{tabular}

quest from the Fachinformationszentrum Karlsruhe, Gesellschaft für wissenschaftlich-technische Information mbH, D-76344 Eggenstein-Leopoldshafen, on quoting the depository number CSD 57295 , the names of the authors, and the journal citation.

\section{Results}

Crystalline $\mathrm{Zn}(\mathrm{OrH})_{2} \cdot 8 \mathrm{H}_{2} \mathrm{O}$ is obtained by slow evaporation of an aqueous solution, which contains the zinc atom and the orotate ligand in the molar ratio $1: 2$.

The crystals of the title compound are isomorphous with those of $\mathrm{Mg}(\mathrm{OrH})_{2} \cdot 8 \mathrm{H}_{2} \mathrm{O}[4,6]$ (space group $\mathrm{P} 2_{1} / c$ with two formula units in the unit cell). Like the isomorphous magnesium compound, the crystal lattice therefore features hexaquometal dications with two monohydrated $\mathrm{OrH}^{-}$ species as counter ions (Fig. 2). The water-rich phase $\mathrm{Zn}(\mathrm{OrH})_{2} \cdot 8 \mathrm{H}_{2} \mathrm{O}$ therefore is not a true zinc "orotate complex", but should be regarded as $\left[\mathrm{Zn}\left(\mathrm{H}_{2} \mathrm{O}\right)_{6}\right]^{2+}\left(\mathrm{OrH} \cdot \mathrm{H}_{2} \mathrm{O}\right)^{-}$. The hexaquo-coordinated zinc cation occupies a crystallographic center of inversion, which relates the two orotate(1-) counter ions and the remaining two anion-bound water molecules. The $\mathrm{Zn}-\mathrm{O}$ bonds in the almost perfectly octahedral dication are similar to those found in other hexaquo complexes of zinc and also to the $\mathrm{Mg}-\mathrm{O}$ distances in $\mathrm{Mg}(\mathrm{OrH})_{2} \cdot 8 \mathrm{H}_{2} \mathrm{O}[4,6]$.

In the crystals of the title compound cations and anions, but also adjacent anions are linked via an extensive network of hydrogen bonds (Table II),

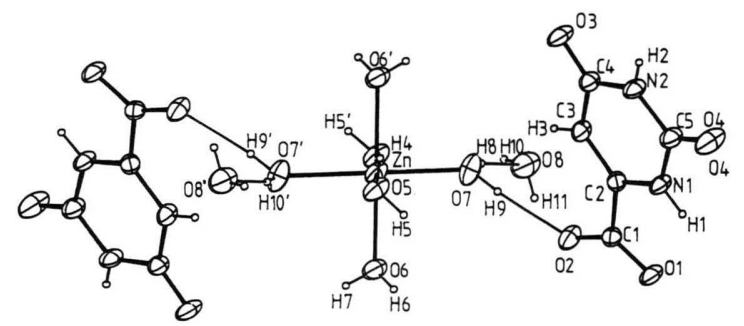

Fig. 2. Representative unit in the crystal structure of $\mathrm{Zn}(\mathrm{OrH})_{2} \cdot 8 \mathrm{H}_{2} \mathrm{O}$ with atomic numbering (ORTEP, displacement parameters at the $50 \%$ probability level; $\mathrm{H}$ atoms with arbitrary radii.). The zinc atom occupies a crystallographic center of inversion. Selected distances $[\AA]$ and angles [ $\left.{ }^{\circ}\right]: \mathrm{Zn}-\mathrm{O} 5$ 2.030(2), $\mathrm{Zn}-\mathrm{O} 6$ 2.122(2), $\mathrm{Zn}-\mathrm{O} 72.118(2), \mathrm{Cl}-\mathrm{O} 1$ 1.250(2), Cl-O 2 1.243(2), C4-O 3 1.231(2), $\quad \mathrm{C} 5-\mathrm{O} 4$ 1.216(3); O 6- $\mathrm{Zn}-\mathrm{O}^{\prime}$ 180.0(1), O6-Zn-O 7 89.6(1), O6-Zn-O 5 89.9(1), O 5-Zn-O 7 94.5(1), O 5-Zn-O 5' 180.0(1), O 7-ZnO 7' 180.0(1), O 1-C 1-O 2 126.9(2). 


\begin{tabular}{|c|c|c|c|c|}
\hline $\mathrm{X}-\mathrm{H} \cdots \mathrm{Y}$ & $\mathrm{X}-\mathrm{H}$ & $\mathrm{H} \cdots \mathrm{Y}$ & $\mathrm{X} \cdots \mathrm{Y}$ & $\mathrm{X}-\mathrm{H} \cdots \mathrm{Y}$ \\
\hline $\mathrm{N} 1-\mathrm{H} 1 \cdots \mathrm{O} 3(\mathrm{~g})$ & 0.803 & 2.231 & 3.001 & 161.2 \\
\hline $\mathrm{N} 2-\mathrm{H} 2 \cdots \mathrm{O} 1(\mathrm{c})$ & 0.859 & 2.046 & 2.880 & 163.9 \\
\hline $\mathrm{O} 5-\mathrm{H} 4 \cdots \mathrm{O} 4(\mathrm{~d})$ & 0.821 & 1.906 & 2.722 & 172.2 \\
\hline $\mathrm{O} 5-\mathrm{H} 5 \cdots \mathrm{O} 1(\mathrm{e})$ & 0.859 & 1.821 & 2.667 & 167.8 \\
\hline $\mathrm{O} 6-\mathrm{H} 7 \cdots \mathrm{O} 8(\mathrm{f})$ & 0.735 & 2.068 & 2.802 & 177.6 \\
\hline $\mathrm{O} 6-\mathrm{H} 6 \cdots \mathrm{O} 2(\mathrm{~b})$ & 0.939 & 1.793 & 2.721 & 168.9 \\
\hline $\mathrm{O} 7-\mathrm{H} 8 \cdots \mathrm{O} 8(\mathrm{a})$ & 0.808 & 2.043 & 2.833 & 165.6 \\
\hline $\mathrm{O} 7-\mathrm{H} 9 \cdots \mathrm{O} 2(\mathrm{a})$ & 0.885 & 1.921 & 2.769 & 160.0 \\
\hline $\mathrm{O} 8-\mathrm{H} 11 \cdots \mathrm{O} 6(\mathrm{~g})$ & 0.733 & 2.303 & 2.969 & 152.0 \\
\hline $\mathrm{O} 8-\mathrm{H} 10 \cdots \mathrm{O} 3(\mathrm{f})$ & 0.788 & 2.103 & 2.889 & 175.9 \\
\hline
\end{tabular}

Table II. Prominent hydrogen bonds in the structure of $\mathrm{Zn}(\mathrm{OrH})_{2} \cdot 8 \mathrm{H}_{2} \mathrm{O}$.

Symmetry positions of atom Y: a) $x, y, z$; b) $-x, y+0.5$, $-z+0.5$; c) $-x+1,0.5+y,-z+1.5$; d) $-x+1,-y,-z+1$; e) $x,-y-0.5, z-0.5$; f) $-x,-y,-z+1$; g) $-x, y-0.5,-z+0.5$.

in which the carboxylate groups, the amide functions of the uracil rings, and the water molecules are engaged.

\section{Discussion}

The present investigation has established the existence of a discrete zinc bis[orotate $(1-)$ ] complex of the composition $\mathrm{Zn}(\mathrm{OrH})_{2} \cdot 8 \mathrm{H}_{2} \mathrm{O}$. The $\mathrm{Zn}(\mathrm{OrH})_{2} \cdot 8 \mathrm{H}_{2} \mathrm{O}$ phase crystallizes upon slow evaporation in air from an aqueous solution. Layering of an identical aqueous solution with acetone, however, yields crystals of a zinc orotate (2-) complex of the stoichiometry $\mathrm{Zn}(\mathrm{Or}) \cdot 5.5 \mathrm{H}_{2} \mathrm{O}$. It is noteworthy that by changing the crystallization technique two different zinc orotate phases can be obtained from identical solutions.

The crystal structure analysis of

$\mathrm{Zn}(\mathrm{OrH})_{2} \cdot 8 \mathrm{H}_{2} \mathrm{O}$ shows that independent hexaquometal dications and $\mathrm{OrH}^{-}$counterions are not only present in the crystal lattice of magnesium bis[orotate(1-)] octahydrate, but also in the analogous zinc compound. Like for the magnesium system, several zinc bis[orotate(1-)] phases with a reduced water content can be obtained as amorphous, but not as crystalline phases upon more rigorous concentration of aqueous solutions (or by spray-drying) [6]. The results of the present investigation indicate, however, that crystalline metal(II) bis[orotate $(1-)$ ] compounds obtained under nonforcing crystallization techniques in general feature hexaquometal dications and orotate(1-) counterions with no direct contacts between the metal ion and the potential carrier molecule. In view of these solid state structures of zinc and magnesium bis[orotate $(1-)$ ] octahydrates it is also extremely unlikely that aqueous solutions of these compounds contain "metal orotate complexes", which would require the $\mathrm{OrH}^{-}$ions to enter the inner coordination sphere of the metal by removing water molecules from their coordination sites. On the other hand, L-aspartate(1-), L-glutamate(1-) as well as pidolate and citrate complexes of a variety of biorelevant metals have been shown to be genuine metal complexes with the organic molecule functioning as a ligand to the metal ions in the solid state and in solution $[3,6,7]$. With L-aspartate, L-glutamate, pidolate, and citrate as well as orotate metal compounds being used successfully in curing syndroms associated with a deficiency of a variety of metals such as calcium, magnesium, zinc or iron, it appears that both simple aquo complexes as well as true complexes with an organic carrier can be used for medication. The exact therapeutic role of the various components remains to be elucidated. The observations of previous and current studies have shown, however, that very specific effects may be operative in each system.

This work has been supported by Deutsche Forschungsgemeinschaft (Leibniz-Programm) and by the Fonds der Chemischen Industrie (Doctorate Fellowship to O. K.). 
[1] P. Karlson, Kurzes Lehrbuch der Biochemie, Thieme, Stuttgart, New York (1988).

[2] J. D. Rawn, Biochemistry, Neil Patterson Publishers, Burlington, N. C., USA (1989).

[3] H. Schmidbaur, H. G. Classen, J. Helbig, Angew. Chem. 102, 1122 (1990); Angew. Chem., Int. Ed. Engl. 29, 1090 (1990).

[4] I. Bach, O. Kumberger, H. Schmidbaur, Chem. Ber. 123, 2267 (1990).

[5] O. Kumberger, J. Riede, H. Schmidbaur, Chem. Ber. 124, 2739 (1991).

[6] O. Kumberger, Thesis, TU München (1992).

[7] E.g. H. Schmidbaur, G. Müller, J. Riede, J. Helbig,
M. Manninger, Angew. Chem. 98, 1014 (1986); Angew. Chem., Int. Ed. Engl. 25, 1013 (1986); H. Schmidbaur, I. Bach, J. Riede, G. Müller, J. Helbig, G. Hopf, Chem. Ber. 120, 867 and 1988 (1987); H. Schmidbaur, I. Bach, D. L. Wilkinson, G. Müller, Chem. Ber. 122, 1427, 1433, 1439 and 1445 (1989); H. Schmidbaur, P. Mikulcik, G. Müller, Chem. Ber. 123, 1001 (1990); C. K. Johnson, Acta Crystallogr. 18, 1004 (1965); O. Kumberger, H. Schmidbaur, New. J. Chem. 15, 401 (1991); H. Schmidbaur, P. Kiprof, O. Kumberger, J. Riede, Chem. Ber. 124, 1083 (1991); O. Kumberger, J. Riede, H. Schmidbaur, Chem. Ber. 125, 1829 (1992). 